\section{Haledirtory Adtress}

$$
\text { ON }
$$

\section{HOSPITAL TREATMENT OF MORBID PREGNANCIES.}

Dhuivered to the Edngurgi Obstetrical Socirty.

By J. : W. BALLANTYNE, M.D., F.R.C.P.E., PHYSICIAN, ROYAL MATERNITY HOSPITAL, EDINBORGH; MEDICAL COLLEGE FOR WOMEN, EDINBURGH.

A BEw weeks ago I received a letter from an obstetrician in England in which he asked me what was the present state of $\mathrm{my}$ project for the establishment of pre-maternity hospitals; and gome time before that I had a request from the editor of one of our medical journals that I should furnish him with some records of cases of diseases of pregnancy treated in the Royal Maternity Hospital here under my care. It seemed to me, therefore, that I might give the information required and comply with the editorial suggestion in this valedictory address; and I was the more anxlous to do so as it happens that I have never up till now brought before this Soclety the subject of pre-maternity hospitals at all.

In November, 1900, I first touched upon the subject of the hospital accommodation of pregnant women suffering from one or other of the diseases incident to gestation, in a clinical lecture on abortlons given in the Royal Maternity and Simpson Memorial Hospital here. This lecture was afterwards published in the International Clinios (Berles $\mathrm{XI}$, vol. Ii, p. 231, 1901), and I quote the concluding paragraph. It ran thus:

Finally, I may perbaps be allowed to say that it has seemed to me that there is a want in our hospital system-the necessity for some speclal institution In which cases of recurring abortion, habitual premature labour, habltual fetal death, hydramnios, and pathological pregnancies in general might be both studied and treated. Such cases are not at present welcome in general hospitals, for there is an objection to welcome in general hospitals, for there is an objection to turning the wards into maternities; neither are they scceptable to the maternity staff, for they are " not at the full term of pregnanoy." There ought, I think, to be some such hospltal gation of the morbid states of pregnancy might be carried on and their treatment elaborated and placed apon a sure basis founded upon experienoe.

Soon after this, on April 6th, 1901, the British Mrdicar Journar published my Plea for a Pre-Maternity Hospltal, in which I stated, at greater length and with all the persuasive force of which my pen was capable, the necessity I thought there was for such an institution, and the advantages, scientific as well as humanitarian, which I fancied would accrue from its establishment. I may quote a few sentences from this article, for it contained all the principles I had to enunciate, anything further that has appeared since having been elaboration of details :

The pro-maternity hospital need not be a separate establishment ; it may quite well be an annexe of the maternity. In time it may come to be of equal size with the maternity, but it must be distinct from the malernity. It will be for the reception of women who are pregnant, but who sire not jet in reception of women who are pregnant, but who are not jet in
labour. In the first place, doubtless, it will be for the reception of patients who have in past pregoanoles suffered from one or other of the many complications of gestation, or in whose present condition some anomaly of 1 he pregnent state has been diagnosed; but in time it may be taken advantage of by more or less normal ambulants-working women, for example, who ought to rest during the last weeks of pregnancy. - When labour pains came on they would be trensferred to the ad jolning maternity, and It would therefore be advisable that the two buildings communlosted by a covered way f for that the two buildings communioated by a covered way ; for of the principles of the pro-maternity would be the conservaof the principles of the pro-maternity would be the conserva-
tion of fotal life, although, of course, not at the expense of tion of fotal life, although, of course, not at the expanse of of the pregnancy with safety to the mother; that would be the ideal. . In a pro-maternity we might be able to study with scientific exactness, not only the pre-eclamptic, but also the pre-albuminaric modifications of the arine, and we might a) so discover the relationship which exists between the abeence of normal thyrold hypertropby and the presence of albumen in the urine.

In May, 1901, the edltor of the American Journal of Obstetrics kindly published my vlsion of the twenticth $\cdots 3$ century, entitled, "A Visit to the Wards of the ProMaternity Hospital." It was my dream of what such a hospltal might be: an. international institution, situated somewhere between France and Germany, manned by a ataff of medical experts of various lands; and with, at the head of it, Dr. Anthony Nathan Patholog, while under him worked Dr. Geburtsmal and Dr. Mondkalb, Germans, Dr. Loenfmalade, a Frenchman, Dr. Embryanowsky, a Russian, Dr. Feto of Florence, Dr. Teras Teratos, of Athens, and Dr. Ariston Hudor, the last named being in charge of the ward for habitual inebriates who were being kept from all alcohollc preparations during their pregnancies. There were to be wards also for the prevention of habitual abortions and fetal death, for the treatment of syphilitic pregnant women with the view to lessen the risk of infection of the fetus, and for the prophylaxis of such hereditary maladies as haemophilia. This artlcle was of course nothing more tban a jeu d'esprit; but it unexpectedly served a useful purpose, for it was translated In full into German by Prolessor Klelnwächter, and appeared under the title of " Eln Besuch in den Sälen des Pro-Maternité-Hospitales" in Der Frauenarzt for September 20th, 1901

Meanwhile several criticisms of the suggested promaternity hospital had reached me. It was suggested, for Instance; that the name was rather mlsleading; that the term was in point of fact a hybrid word. I intended it to be understood as meaning a hospital into which pregnant women, suffering from some of the maladies of gestation, or pregnant of infants who might be diagnosed as deformed or diseased, should be admitted prior to their delivery in a maternity hospital. I used the word " pro' In Its Greek sense of "belore" or "in front of," not in its cecondary Latin one of "In favour of." I therefore changed the name to "pre-maternity," which more clearly indicated my meaning, and I have since then continued to employ this word. Other criticlems whlch reached me were that I was not proposing anything new ; that I was advocating a place for the reception of unmarried pregnant women, where they might get every attention, medical and hyglenlc; that I was thus making things easler for fallen women, and possibly even encouraging what every one wished to hinder. It was pointed out by Professor Kynoch in the British Medioal Jodrnal (April 13th, 1901) that pre-maternity hospitals had existed as far back as the seventeenth century, there having been wards for the femmes enceintes in the Hôtel-Dien at that time. Professor Kynoch, however, admitted tbat patlents entered the Hotel-Dien at an early date of their pregnancy to ensure secrecy as to their condition, and not to obtain pro-treatment. These criticisms led me to take up the subject of Hospital Accommodation for the Pregnant Woman in an introductory lecture to my class in October, 1901. In a summary of that lecture, published in the British Mricical Journal for October 19th, 1901, it is stated :

That Dr. Ballantyne dld not ask for an asylum, or reformatory, or secret maternity; such institutions already exlsted, and doubtless had thelr function. What was required was a medical institution or part of one, a hospital or part of a hospital, In which the medical wants of the pregnant patient and of her unborn ohild would be considered first.

Let me say again, now, that I fully appreciate the good work that is being done in such places as the Edinburgh Rescue Shelter at 18, Graham Street, and at the Lauriston Home for Maternity Rescue Work; Indeed, through these Institutions I have, on several occasions, received into the Maternity Hospital cases of morbid pregnancy which might otherwise have not been recognized as pathological until labour supervened, and which might therefore have had much less satisfactory terminations from the medical standpoint. But my intention was not to agitate for the establishment of another home of that kind. What I asked for was a hospltal for the reception of women suffering from the diseases of pregnancy, a hospital the entrance into which was not given to a woman because she was married, nor yet because she was unmarried, but solely because she was ill and pregnant. It was my bope that, just as the Maternity Hospital contains marrled women as well as nnmarrled, so the pre-maternity hospltal's beds would be open to all women suffering from the maladles incident to gestation, whether they were legitimately or illegltimately pregnant. The Ideal would be a hospital in whlch all the beds were 
occupied by marrled women, bat no woman would be refused because she was unmarried. The permission to enter would be always medical; the patient would be admitted because she was ill and pregnant, or beeanse she was pregnant, and had in previous pregnancies developed morbid states in herself or in her unborn infant which it was supposed might by prophylactic measures be prevented.

It was in July, 1901, that my hopes regarding the establishment of a pre-maternity hospital, which had been drooping somewhat, were revived by the recelpt of a letter from a friend who had all along thought well of the proposal. This letter contained the welcome intelligence that the writer had given a sum of money $(£ 1,000)$ to the Edinburgh Royal Maternity and Simpson Memorial Hospital for the endowment of a bed to be used for the treatment of patients suffering from the diseases of pregnancy. The bed was named the Hamilton Bed, in memory of Professor Hamilton, who had so much to do, one hundred and ten years before, with the founding of the Edinburgh Maternity Hospital (1791). In November, when Sir Alexander Simpson took over the hospital, he was able to open the Hamilton Bed by putting into it a patient suffering from hydramnios; and, as I acted as assistant physiclan at this time, I had an opportunity of superintending the four or five cases treated in it during the next three months. The case of hydramnios, which was also one of vomiting, had a somewhatcurlous termina. tion, to which I shall make reference when I come to record some of the results of treatment in the Hamilton Bed.

The establishment of this special bed in the hospital stimulated me to fresh efforts to bring the idea of a pre-maternity hospital before the profession, and on January 11th, 1902, I published in the British MrdioAI JOURNAL a lecture (given in the hospital on November 6th, 1901) on "Maternities and Pre-maternities." In this lecture I restated the case for the pre-maternity. I made known the fact that there was now in the Edinburgh Maternity Hospital a bed set apart for the study and treatment of the diseases of pregnant women; and medical men in Edinburgh and the neighbourhood were not long in sending in sultable cases. Indeed, in February, 1902, a short article on the Hamilton Bed and on the cases whlch had already been treated in It appeared in the Scottish Medical and Surgical Journal; it was from the pen of Dr. Oliphant Nicholson. There were also about this time several other encouraging occurrences. For instance, in the Lancet of November 2nd, 1901, there appeared a leading article entitled, Puerperal Eclampsia, from which I quote the following paragraph

We are inclined to think that if a correct knowledge of the causation of eclampsis is ever to be arrived at, attention must be mainly directed to the pre-eclamptic stages of the disease. Further investigations must be devo red to eareful observetion of all departures from the normal in the health of the pregnant woman. Then, and then only, will it be possible to practise woman. Then, and then only, will it be possible to practise preventive medicine-the hyghest art of all-in the case of the
pregnant woman and of the fetus in utero. The opportunities of a scientific study of the various problems connected with pregnancy are at the present day almost nil; the length of time such patients remain in lying-in hospltals before their confinement is too short for any prolonged observations to be made, and work of this neture is impossible in private practice. It is an encouraging sign to see that, mainly owing to the strenuous advocacy of Dr. J. W. Ballantyne, and the generosity of Dr. Freeland Barbour, a bed is to, be endowed generosity of Dr. Freeland Barbour, a bed is to; be endowed and set apart for the study of the diseases of pregnancy in the more worthy object for philenthropy then the endowmentio such beds in some of our large maternity hospitals where the diseases of pregnancy and of the unborn child could be investigated .with all the advantsges of modern science. It is by research in this direction that we are most likely to gain a true knowledge of the problems of eclampsis and of the best means of preventing this dangerous complication of pregaaney.

It was about this time also that the Britrsn MrDion Jotrasar, In a leading article (October 19/h, 1901) upon Dlet in Pregnancy, more especially in connexion with Prochownick's method of influenclng the size of the fetus and the character of the confinement by altering the diet of the mother, affirmed that

the trath of Proohownick's statements could only be adequately ascertained in such an institution 8s the pro-maternity (or, more correctly, pre-maternity) hospltal may yet turn out to be.

Several American medical journals, in reviewing the first volume of my work on Antenatal Pathology, took occasion to touch upon the advisability of establishing pre maternity hospitals for the observation of pregnant women in whom gestation was not running a normal course; the Medical Review, for instance, "heartlly supported the suggestion," while the Boston Medical and Surgical Journal (April, 1903)-spoke of " the Idea of a prematernity hospltal which is fast coming into favour, and is undoubtedly bound to have a place in connexion with lying $\cdot$ In hospitals in the near Inture."

It was, therefore, with great interest that $I$ heard in December, 1803, of the proposal that the new maternity in connexion with one of the London colleges should be provided with a ward for the diseases of pregnancy. The information came to me in a letter from the obstetric physician, and in reply I gave him all the Information I possessed on the subject, including, of conrse, a reference to the kind of cases which were being deslt with in the Hamilton Bed. During the past three or four years I have written almost nothing on the subject of prematernities, for I felt-and, I think, rightly-that the profession had accepted the statement that such institations were desirable and almosi necessary for the further development of the practice of obstetrics and for the safeguarding of fetal life. I was convinced also that in time funds would be forthcoming for the bullding, furnishing, and staffing of pre-maternity wards, pavilions, or linked hospitals in connexlon with existing maternities. I broke silence once more, however, at the National Conference on Infantlle Mortality, held in London on June 13th and 14th of last year, and what I eald then I may be permitted here to repeat.

When a pregnant woman is attacked by a disease, and more particularly by a disease which is due to her pregnancy, It is it is even diffienlt to get her into a hospital at all, for meny maternity hospitals do not receive patients until they are in the first stage of labour, and most general hospitals are chary of admitting to their wards women who are near confinement And yet, as is well known, the diseases of pregnanoy are mast deserving of trestment in many instances, while in some cases a mother's and a chlld's life may. be saved thereby. It was with reasons such as these in my mind that I proposed the establishment of pre-msternity hospitals in olose ansociation with our maternities, but not, if possible, within the same with our maternities, but not, If possible, within the same four walls, and not under the same nursing and administranot because they were married, not becanse they were unmarried, but simply because they were thesubjects of pathological pregnancies. In such pre-maternity hospitals thediseases of pregnancy would be made the subject of specisl study, and the besc trestment, keeping in mind both mother and innborn e carried out. Falling the immediate construction of such institutions, I recommended the setting spart of one or two wards, or one or two beds, in the maternity hospital for the reception and treatment of pregnant women suffering from the maladies of pregnancy. My reason for pushing the larger scheme is that there is evidence that the residence of pregnant women In a maternity hospital for weeks or months before confinement has been shown to be not entirely free from risk. Apparently the association of the two classes of case, the pregnant and the puerperal, is not for the best Interests of the former; the want of exercise and interest is not good; and in a word there isos laok of the special conditions of environment and diet and treatment which a pregnant woman needs, and which are not the same ss those reguired by a puerperal one. At the same time, even the single bed that we have in the Edinburgh Maternity Hospltal has been a benefit. It has, for instance, been a comfort for medioal practitioners in the neighbourhood to know that they could send sulteble ceses into the hospital with the sssurance that they would be taken in, not. out of eourtesy as it were, bat by right; and I know from experience that the trestment such patients have recelved - has ibeen of palne in rerting nearly normal state of health before the supervention of labour with all its risks. But it is, 1 think, unneesssary to elaborate arguments in farour of pre-maternity hospltals; they are self-
evident, and further, the principle of them has been admitted In Amerios and in this country oince I published my ples for them in the BRTPIsH MrEDIGAI JOURNAL In 1901, and in several other pleoes and at several other times since then. It seems to me that without some such institations the study of the oarses and the recognition and treatment of the diseases of pregmanoy mast continue to be greatly hampered and hindered. To mention only one advantage before passing from this subjeot to another, I may name that of being able to check the diet and the drink in cases of albuminuria and the diseases due to alcoholism.

If further proof were needed that the question of the dezirabllity of pre-maternity hospitals had passed out of 
the personal Into the general phase it is to be found in two circumstances which have recently come under my notice. One is the fact that Dr. T. Arthur Helme, in his address on The Unborn Child, delivered in Manchester on June 20th, 1907, ${ }^{2}$ thought it sufficient to affirm that one of the duties now resting upon the medical profession and the State was the provision of hospitals for the reception of women during pregnancy. Dr. Helme used no arguments; gave no details, and evidently anticipated no objections. Another incident whose signlficance cannot, I think, be missed is recorded in the following paragraph, which appeared in the British Mrdidar Jouranar for January 20th, 1906.

In honour of the German Emperor and Empress's approaching silver wedding, and to oarry out one of the favourite ideas of the Hmpress, Charlottenburg has deolded to ereat a small model lying-in and infants' institute. There are to be 30-beds for women expecting confinement, who are to be allowed to stey on antil their ohild is 3 months old, and 30 beds for infants to be fed artificially.

I presume that some of the beds, at any rate. will be set aside for pregnant women who are 111 . When Germany has got its pre-maternities there wlil doubtless be hope of their early instltution in this country.

\section{Cases Treated in the Hamilton Bed.}

It generally happens that theorles, when tested by experlence, work out somewhat differently Irom what was expected, and it was 80 in the case of the Hamilton Bed. I anticipated that as soon as the bed became available for the treatment of cases of morbid pregnancy we should have a patient under our care in it for a period of, say, a fortnight or a month; that during this period we should have time for exact researches on the functions of the body, incliding analyses of the urine, examinations of the blood, and investlgations of faeces, etc.; that then there would be time to institute some rational method of treatment and judge at one's leisnre the results. But I was calculating without taking into account the proverbial uncertainty of the supervention of labour. Thls was borne out in the case of the very first patient, who occupied the Hamilton Bed.

\section{Hydramnios with Vomiting.}

The patient, a multipara, 37 years of age, believed herself to be in the seventh month of her eleventh pregnancy. She had had a somewhat disastrous reproduetive history. Her first pregnenoy ended in the birth of twin girls, both of whom dled about a fortnight after birth; her second pregnancy terminated prematurely at the elghth month, the ohild being dead-born ; the next four labours seem to have been normal, bat all the infants, males, died shortly after birth; and the next four gestations resulted in the birth of boys all alive next four gestations resulted in the birth of boys, all alive
still. She had suffered from vomiting, more especially during the past three months, and was emaciated. Her palse on admission was 109, and her temperature was $99^{\circ}$, rising to $101^{\circ}$ the next day. After she had got a good action of the bowels her tempersture fell below normal, but her palse remained rapid and was seldom below 100 . The circumference of the abdomen at the level of the umbillcus was $34 \frac{1}{2}$ in.; the fandus uteri was felt about 2 in, below the ensiform cartilage the uterus was greatly distended with flaid. ballottement was essily got, the fetal hesd was felt at the fundus, and the fetal small parts could be palpated and seemed to be numerous. fetal small parts could be palpated and seemed to be numerous. No fetal heart sounds could be heard, but the uterine bruit was audible. Keeping in mind the frequent assoclation of hydramnios and fetal deformities, I expressed the opinio

The first matter, however, which engaged my attention was the relief of the sickness; and for this purpose the pation was put on a diet of milk, was kept resting in bed, and had the bowels regulated. In a day or two she was able to take and to retain some porridge Then I med was able to take and to whether I could not reduce the amount of lifuor amnil by the administration to the mother of frequent small doses of magnesium sulphate; I thought I might in this way get a hint as to whether there was free circulation of the liquor amnil from the mother's circulation inte the amniotio cavity and back again. This treatment was commenced on November 11th ; but on the s8me night labour pains came on, and when I arrived at the hospital the next morning the resident physician introduced me to twin girls who had been born at an early hour. The labour had been rather slow, and it had been found necessary to rupture the membranes, when quantity of liquor amnil, estimated at about two pints, had quantity of liquor amnil, estimated at about two pints, had
escaped. Soon afterwards the first chlld was born, the head presenting ; a minute later the second ohlld was born by the breech; and the single placenta was expelled two minutes and $a$ half later. The twins had a close resemblance to esch other. the first weighing $3 \mathrm{lb}$. $15 \mathrm{oz}$. and the second $3 \mathrm{lb}$. 11 oz. After labour, the pulse and temperature became normal, and tre puerperium was uninterrupted: Such was the afmost ludicrous termination of our first attempt to forecast the fature of antenatal' affuirs.

This case was the first that was treated in the Hamilton. Bed; but I find in the offioial record of the hospital that another and an earlier caise of vomiting in pregnancy was credited to it. When Professor Simpson and I took over the hospital on November 1st, 1901, there was then in the wards a patient believed to be suffering from

Hyperemesis Gravidarum.

It was calculated that she was two and $a$ hilf months pregnant, and it was said that she had been rejecting her food for nant, and it was said that sho had been rejecting her food for pital, and had during the last week of October been sent in for further trestment- - iz., the induction of abortion. Her temperature was subnormai ; her palse was 88, small, thready, but of high tension; and there was a trace of blood in the urine. She was a nullipara, 30 years of age. She was pat upon rectal fesding; no food at all was given by the mouth. The nutrient enemata consisted of milk, brandy, and meat juioe, with Under this treatment her conditlon had impioved somewhst:but soon after November lot she besme worsed somewhat.; ture remaining subnormal, while her pulse rose to 100. tound ber seriously ill ; she was much emaciated ; the abdomon was flat, almost scaphoid ; the mammary changes were not characteristio of pregnancy, and the uterus was found lying retroflexed and enlarged. Under on ansesthetic I tried first to replace the uterus, and I partially succeeded, but it seemed to be fixed In the pelvis by adhesions; then $I$ attempted to dilate the cervix digitally, in the hope that the stretching might reflexly influence the vomiting. The firmness and resistance of the cervical tissues were well marked, and it was at this stage of the procecdings that I began to and it was at this stage of the proceedings that I began to
doubt the existence of pregnancy. Having once got this Idea doubt the existence of pregnanoy. Having once got this idea
into my mind, I made another abdominal examination, and thought that I detected something like a tamour in the eplgastric region, and that the cause of the vomiting was gestric.

The patient was sent into the Royal Infirmary, whence in a day or two came the news that a small fetus and decidual membranes had been expelled from her nterus. The pstient recovered; but it was long before my confidence in my powers of antenatal diagnosis was restored.

\section{Epilepsy (?) in Pregnancy.}

Another case of morbid pregnancy was treated in the Hamilton Bed during the winter quarter of 1901-2. The patient was 26 years of gge. She was a dwarf, her height boing only $4 \mathrm{ft} .4 \frac{1}{2}$ in. Her first pregnancy had terminated three yesro previously in an embryalcis, and it was calculated that the child had boen dead for a week before blrth. Her second gestation onded spontaneously at the sixth month; she had no medical attendence in this confinement. During both the first and second pregnency she had suffered from fits not had any previous to her first pregnsncy, and they did not happen during the labours. They were less severe in the socond gestation. She was now (November, 1901) pregnant for the third time, and it was calculated that she had arrived at five and a half months. The fits had been troubling her during the whole course of this gestation; she described them as fainting fits ; and she stated that she could generally tell when they were coming on. She had been surrounded by people suffering from epilepsy; her husband took bad epileptic selzures, and so did her stepfather and a stepbrother There was not, however, any history of epilepsy in any of her blood relations. About the third month of the present pregnancv the pasient began to experience difficalty in locomotion, and lately this difficulty had become so aggravated that she was Of course the urine was at once examined; it contained no albumen or sugar; urea was present in sufficient amount $(7 \mathrm{gr}$. to $1 \mathrm{oz}$ ), considering the patient's size and the diet she was pnt on. Daily estimations were made of the urine during the whole time the patient was in the Hamilton Bed, a period of eight weeks. Physical examination revealed the existence of a pregnancy of about the age indicated by the menstrual history ; the fetal heart was heard in the upper part of the uterus where also the head of the fetus was felt. The pelvis was ound to be small and irregular; the external conjugate was estimated at $6 \frac{5}{8}$ in., and the diagonal conjugate at nearly 4 in., but this was atterwards found to be an over-estimate.

For a few dajs the patient was put upon a milk diet, but this was discontinued when it was discovered that the kidneys were acting normally. It was then decided to try the effect of the Prochownick proteld diet in this case in order to keep the size of the child small and 80 fanllits thought might be induced sbout the seventh month and half. Neither the milk diet nor the Prochownick produced any effeot upon the fits; bromides were administered for a time, and they were followed by valerianstes, but neither of these drugs had any apprectable influence. Dr. Eawin Bramwell saw the patient on several occasions - once while se wes in a convalsion. Fre inclined to the belief that the case was one of a group recently (1901) described by Sir Wm. Gowers, In which the symptoms were those of a functionsl or co:caHed hysteroid attack, dependent; however, apon 
translent and almost unnoticed attack of petit mal, or true epllepsy, which was, therefore, the underlying and fundsepliepsy, which was, therefore, the underiying and fundsmental condition. Sphygmographio tracings were taken on several oocasions by Dr. Oliphant Nioholson, and were found to show no increased arterial tenslon. There was no sign of heart disease ; the heart was not hypertrophled. The fits were - Fery erratic in their inoldence and irregalar in their duration ; the longest one observed lasted for half an hour. After complaining of dizziness the patient shat her eyes and becsme unslightly rigld, sometimes only on one side; the tendon reflexes were very active during the fits; slight squinting was observed. The tonene wss never biten, there was no fosming at the moutb, and there was no cry. Some twitching was now and again noilced. A profase quantity of pale urine was never passed after any fit, neither was there any globus hystericus, or blepharospasm, or contraction of the field of vision. The incldence of the fits was not affected by the presence or absence of other persons in the ward, nor by the making of vaginal exsminations; there was no diurnal nor nocturnal prevalence of the selzures. Bablnski's sign was never deteoted, and the pupils resoted, bat somewhst sluggishly, to light and accommodation. The mentel state was quite satisfactory. Although the pationt's palse-rate remsined normal and the temperature was not raised, the general state normal and the temperature was not raised, the general state
was not good, for there was great weakness and almost complete insbllity to stand or walk. No doubt the unsatisfactory general condition of the patient had mach to do with the anfortunate terminasion of the case. It was decided to induce labour about the middle of January-namely, at the close of the seventh month; but when the time came the chlld proved to be larger than had been expected and the conjugata vera smaller, and, as the patient and her husband were anxious for living child, Csesarean section was performed by Professor siving child, Csesarean seotion was performed by Professor the mother died on the fourth day, for, although there had been no rise of temperature, the pulse had remained fast and weak, and signs of septic infection of the abdominal incision had appeared.

Thls was a sad ending to a case which had been so long in the Hamilton Bed; and, although the patient did not succumb during her pregnancy but after delivery by Caesarean section, yet I cannot help thinking that her prolonged stay in bed in hospital in a ward in which puerperal cases were being nursed was in some measure prejudicial. Further, the carrying out of special methods of reglmen and dlet, such as were adopted in this case, is a matter of some difficulty in a maternity hospital, and I doubt whether it was perfectly parformed here. I was led by this experience to hope for a separate bullding for the management of pregnancy cases, or at least for a separate ward, and I have since been able to keep these prematernity patients more strictly to themselves. I have also aimed at benefiting them in the hospital and sending them out again to be for some time at home before the supervention of labour. I think that it is in this way that a bed or some beds in a maternity hospital will prove of most service for the treatment of the dlseases of pregnancy. Another case of epilepsy in pregnancy has been recently treated in the Hamilton Bed during my quarter, and I pursued the above-named plan with it. The patient came in with a history of frequently recurring fits, and it was thought at first that they had been eclamptlc in thelr nature. There was, however, no albumen in the urine, nor were there any other signs of renal.disease. It was discovered that ever since her first pregnancy, ten years prevlously, this woman had suffered from convulsive seizures, almost certainly of an eplleptic nature. It could not, however, be traced that they were consistently worse during the gestations. She was kept under observation and treatment in the hospital for three weeks, and then sent home as she wag not yet at term.

It is with a feeling of relief that I now pass from these early and disappointing cases to some more recent and more encouraging experiences. I shall here refer to three cases of eclampsia whlch all occurred durlng my quarter in 1905 , for, after all, if the uselulness of treatment during during pregnancy is to be tested and established, it must be in connexion with the most serlous complications of gestation.

\section{Cashes of Fclampsia.}

Case 1.

Mrs. R, aged 33, was sent into the Royel Maternity Hospit il by Dr. George Dickson on August 24th, 1905. She wos pregngn for the fifth time. Her first three pregnancies terminated in normal fall-time labours in 1897, 1899, and 1901 respectively; the first child was a boj, and the second and third were girls. The fourth confinement took place in September, 1903 ; the The fourth confinement took place in September, 1903; the child was a girl ; the labour was easy, bat there was some inflammatory trouble In the puerperlum. All the Infants sur-
vived. Bhs nursed her lagt child till she was fourteen months old. She did not menstruate whilst nursing, and she has not menstrusted since, so that the date of commencement of the present pregnancy cannot be estimated. She lelt stirrage, however, in the beginning of April, 1905, and expected to be confined about the end of Angust. During the whole course of the present preguanoy the patient has been in very poor health. he has had headsche, constlpation, faintness, glddiness, great frequency of mictarition, dyspnoes, and cough with frothy expectoration. All these symptoms became worse as pregnancy procesded. During the early months she noticed some oedema the oedema became more marked and generalizgd over the body.

Daring the week before her admission to the hospital the patfent did not get a single motion of the bowels. She took a pill on the evening of August 23 rd, and a seldiltz powder the next morning, but with no result. She felt very tired on the 23rd, had severe frontal headache, took no food, vomited several times, was dizzy, and could not see well. She spent the night walking about restlessly. On the morning of the 24th the same symptoms continued, and at 12 noon she threw herself on the bed thoroughly tlred out. At 1.15 she took a fit, described as "like epilepsy." Her tongue was badly bltten. described as "like epilepsy." Her tongue was badly bitten. The fit lasted ten minutes, and before she regained consciousgreater severity. Drowsiness continued for an hour or two, and theresfter she becsme conscious of her surroundings. It may be added that her previous health had been good; she might have kldoey disease.

At 5 p.m. she was admitted to the hospital. There had been no farther fits slnce the second one, and no more vomiting. She was a big strong woman, and somewhat plethoric. Her lips were cyanosed, and her breathing was heavy. The pulse was 120 , regalar, fall, and of moderately high tension. The temperature was $99.6^{\circ}$ and the respiration-rate 25 . Her face was of a dusky colour, and was swollen; her papils were contracted and equal, and there was slight oedema of the legs. There were the usual signs of a full-time pregnancy. It was now that I first saw the patient. She was dull or semicomatose, mattering when spoken to, bat not apparently realizing her surroundings. At 5.30 p.m. (half an hour after admission) she had an eclamptic seizure. Chloroform was given, and a half-grain of morphine hypodermlcally. A large water enema half-grain of morphine hypodermically. A large water enems
was also given, bat with no results. Three pints of saline were was also given, bat with no results. Three pints of saline were
run in under the breasts, and hot bottles were placed round her. ran in under the bressts, and hot bottles were placed round her.
At 7.30 she was very restless, shouting, and almost maniscal. A At 7.30 she was very restless, shouting, and almost maniscal. A
third of a grain of morphine was given hypodermically. Another fit occurred at 9.30, during which chloroform was administered. Two minims of croton oll were given by the mouth. At 11 p.m. she was excessively violent and could not be held in bed; 6 grains of ohloral hydrate in water were given hypodermlcally. At 1 a.m. (August 25th) she was quleter ; 5 grains of chloral were given. At 3 a.m. she had ano ther fit, and she got 5 grains of chloral hypodermically. An hour later (4 a.m.) an enems of chloral hypodermically. An hour later (4 a.m.) an enems consisting of $2 \mathrm{oz}$. Of castor oll, 2 oz. of Henry's solution, and at the morning visit she was much better ; the bowels had moved well; there had been no more fits sincs 3 o'clock, and she was more ratlonal. Tae urine becsme solid on bolling. Chloral and bromide of putassium were now given by the mouth. Stesdy improvement commesoed under a striotly milk diet and jalsp for the regulation of the bowels. Two days later (Angust 27 th) the urine had a specific gravity of 1014, and was acid in reaction; it contained granular casts bat no blood; the ures was 7 grains and the albumen 086 grain per ounce. There was marked optlc neuritis and some small baemorrhages were seen in the left retins. On August 29th the pulse was soft and the oedems had gone. The patient was on strictly milk diet. The albumen was now 0.65 grain per ounce.

On September 1st labour psins came on at 3 p.m. The positlon was L O.A, and the fetal heart was clesrly beard. At $10 \mathrm{p}, \mathrm{m}$. the os was as large as a fire-shilling plece, and the membranes were protrudiog. At $11 \mathrm{p} \mathrm{m}$. the membranes ruptured and fire minutes lat 9 r the chlld was born. The afterbirth was delivered without difficulty and there was no haemorrhage. The infant, a female, was poorly nourished, and weighed only $3 \mathrm{lb}$. $11 \mathrm{oz}$.; she was put in the incubator. Milk diet for the mother was continued. On S jptember 7 th there was marked improvement in both mother and infant, but there was still a good deal of albumen in the urine, and on September 19th, when the patient left the hospltal, there was still a trace. The child was thriving. In January, 1906, Dr. Dickson was able to report that the patient had made an uninterrapted recovery, The infant also had done woll and was strong and healthy.

\section{Case 2}

Mrs. 8., aged 22, was admitted to the Rojal Maternity Hospital on September 2nd, 1905. She was sent in by Dr. Bullivan, and it was stated that she had had two eclamptic selzares the preceding evening She was a primipara. She last menstruated on Chrlstmas Day, 1904. She was living then in Hong Kong. Her health then became pojr; she suffered from headaches; her face was puffy in the mornlngs. Her urine was scanty, dark brown in colour, and was passed with so much paln that she dresded the act of micturition.
These symptoms have persisted till the present time. She 
left Hong Kong in Aprll, 1905, and reached London in June, after a very rough passage, during which she suffered from both morning sickness and sea-3ickness. She made no attempt to diet herself elther in Hong Kong or on the vojage. $8 \mathrm{be}$ had lately come to Edinburgh. Quickening had occurred at the sixth month. Tae headaches, always occipital in position had been very troublesome, and the swelling of the face had become more marked.

A week before admission all her symptoms became more severe; the hesdaches were so bad that the patient could not sit down; the oedema spread to the whole body, and she was passing very little urine, not more than a breakfastcupful in the passing very little urine, not more than a breakfastcupful in the
twenty-four hours. She was seen by Dr. Sallivan on Septemtwenty-four hours. She was seen by Dr. Sallivan on Septem-
ber 1st. He put her on milk diet. The same evening, when she was talking to her mother, she suddenly began to twitch all over; the movements lasted for a few mlnutes, and were followed by unconsclousness. Her tongue was bitten. A few half a grain of morphine hypodermically.

Bhe was admitted to the hospital the following morning, having had no further fits during the night. There was having had no further fits during the night. There was oedema of the face, with slight exophthalmos. There was limbs. The pulse was small, hard, and beating at the rate of 80 per minute. The urine became quite solid on bolling there were 7 grains of ures to the ounce. The patient was conscious, and complained much of occlpital headache. Her abdomen showed slgns indicating pregnancy at the seventh or elghth month. No fetal heart could be heard, but the patien thought that she could detect fetal movements. The fetal hesd was te

I took occasion to examine the patient soon after her admission, and I called the resident's attention to the fact that the part regarded as the fetal bead was too soft for the head and too large for the breech. Thls observation is of special
interest in view of the condition of the infent's head Interest in view of the conditio

The patient was put to bed between blankets, and was surrounded with hot bottles. She was given nothing but milk. The bowels were opened freely with compound jalap powder. Improvement begen and continued for a week, the quantity of urine steadily increasing, and the headaches becoming less arere; then, however, the headache again got worse and was praotically constant, and the eyesight became dim-at first a white cloud came over every thing, and later every thing seemed black. The ophthalmoscoplc examination showed no distinct optio nearltis, but there was slight swelling of the right disc at the apparent lower and nasal quadrant, and the vessels were somewhat dllated; the pulse tension was high; there were slight labour pains; the amount of albumen in the urine increased to 1 grain $p 3 r$ ounce, and the urea was estimated at 7 grains per ounce. Theskin and bowels were kept acting freely, and the grave symptoms pase of off. From the 9th to September 13th the patient remained in a fairly satisfactory state. Then labour pains csme on, and at 4 a.m. on September 14th the os was found to be about three-quarters dilated, and through it a large soft presenting part could be felt ; further examination disclosed bones with large membranous intervals in the part palpsted at the os; the diagnosis of hydrocephalus was thos made, and the obscurity of the prevlous examination of the fetal presentation was cleared up previous examination of the fetal presentation was cleared up. cephallc head was born as a long sausage-shaped mass. The cephalic head was born as a long sausage-shaped mass. The skin of the scalp was seen to be peeling off in various places, delay in the blrth of the base of the craniam, Dr. H. J Dunbar (one of the residents) applied the forceps, and with no great difficulty brought the head down. The infant, a female, exhibited it may be concluded that it died elther at the time when the eclempsia occurred (Beptember 1st), or when the aggravation of symptoms took place (September 9th). The aggravation of symptoms took place (September 9th). The head was typically hydrocephalic, but there was no spina blfida
or other malformation. The placenta showed one extensive haeimorrhage, situated centrally.

The patient recovered well from the delivery. No fits occurred at labour or in the puerperium, and the symptoms which had been so troublesome before delivery disappeared. Immediately before labour the albumen in the urine had been 1 delivery) the urine had a specific gravity of 1030, the urea was the same ( 7 grains per ounce), and the albumen was 0.86 grain the same ( 7 grains per ounce), and the albumen was 0.86 grain p.12 grain per ounce, and the urea had risen to 8 grains per ounce. On Saptember 25 th the anslysis was practically the eame, and the specific gravity was 1015 . On the 28th there was no longer any albumen, the urine was clear and without deposit, and the specific gravity was 1015 . The patient left the hospital two days later, stating that she felt perfectly well. There was no oedema.

Case 3.

Mrs. Y., aged 35, was sent Into the Royal Maternity Hospital on September 24th, 1905. She was pregnant for the third time. The history of her previous pregnencies was as follows: She geve birth to an eighth month child In December, 1903 ; it was
desd-born. For three weeks before the confinement the patient n as troubled with swelling of the face and feet, so that she was unable to go about. She took her ordinary diet; her urine was not examined. Her second confinement occurred in October, 1904 ; It was at the sixth month, and the fetus was not viable. She never felt quickening in this pregnancy, and there was no swelling of any part of her body. She was now living in Portobello, and Dr. Titterton was call ed to attend her after the expulsion of the $f \in$ tus.

The present pregnency (the third) has the following history : The last menstruation was on April $7 \mathrm{tb}, 1905$. In June the patient began to suffer from severe headaches; ber sight ws oim at times, and sho had some giddiness Sho consulted Dr. Titterton, who examined her urine, and told her that her kidneys were affected. She was pat on a diet consisting almost entirely of milk. About six weeks later Dr. Titterton told her that her water was all right again, and she began to take ordinary food, and continued to do so till September 18th, the day of the Royal Volunteer Review in Hainburgh. On that her sight was dim at times, that the urine was very thick, and that she felt "as if she could not be bothered to do anyand that she felt "ss if she could not be bothered to do anyher. She was put to bed, and kept again on a restricted diet. During the following week the same symptoms continued, and the paitient remained in bed. She noted the fetal movements which had occurred first at mid-term (she was now six and half months)

She awoke on the morning of Sunday, September 24th, having slept soundly all night, and remembers seelng her husband making ready the breakfast. After that all was a blank to her till she regained consclousness in the hospital. Her husband said thet without warning his wife took a fit ; she did not cry out, bat her face and limbs twitched violently. This occurred at $10 \mathrm{a.m}$. ; s second fit followed at 11.30 ; a third took place at 4 p.m. When the patient was coming up in the ambulance to the Maternity Hospital; and a fourth super. vened Immediately after her arrival at 4.30. During the fit which occurred in the hospital chloroform was administered. The convulsions were of the usual eclamptic character, and were very violent. The tongue had been bitten in the preceding fit; and the patlent's clothes were soaked in urine. Five grains of chloral hydrate were injected into the glateas maximus muscle, and the patient was put to bed between blankets, with hot bottles around her, and near a large fire. She was quite unconsclous, and was very restless, muttering constantly and incoherently. She was a strong, muscular woman, and she tossed about so violently that it was necessary edge.

There was slight oedems of the legs and face. The rlngs of the traches were easily felt, showing that the normal hypertrophy of the thyrold gland was not well marked. She had an appesrance slightly suggestive of myxoedems. The pupils were somewhat contracted and equal, and the lips were shightly cyanosed. The palse was 100 , and the artery was markedly contracted ; the temperature was $98.2^{\circ} \mathrm{F}$. An enems was was then given 2 minims of croton oll in butter. The skin was quite dry, so after she had been an hour or two in the hospital she was put in a hot pask, but even this did not cause the slightest perspiration. About four hours after admission he besme more restless and was given 10 grains of chloral she becsme more restless and was given 10 grains of chloral hydrate by the mouth; this she swallowed fairly well, but as It seemed to have very little effeot the dose was repeated in
two hours. She then besame quileter and had a fairly gojd two hours. She then besame quieter and had a fairly good
night. It should be added that a plnt of saline was infased subcutaneously during the evening.

On September 25th she was still semi-conscious. She could not be made to speak at all ; she was restless, and kept tossing about and muttering occasionslly. The skin was dry and the temperature $99^{\circ}$; the pulse was 100 and of high tension. Two small watery motions were the result of the croton oll. As it seemed to me that the case was one of the thyroid type, I ordered the administration of thyrold extract (10 grains) at $230 \mathrm{p} \mathrm{m}$. Two hours later the patient was fully consclons; she was persplring freely ; she could answer questions rationally, and realized where she was; and her pulse was distinctly softer in character. Five-grain thyroid tabloids were now ordered to be glven every four hours. The urlne had a specifio went quite solid on boillng.

She was much better on the following day (September 26 th) She had had two loose motions in the twenty-four hours, and had passed about $30 \mathrm{oz}$. of urlne. She talked quite senslbly, and seemed happy. She was kept on a strict milk diet. She was still improving on September 27th. The tension of the
palse was not so high. Fifty oz, of urine ware passed in the pulse was not so high. Fifty oz. of urine were passed in the
twenty-four hours; it still went nearly solid on boillng, and howed a coplons deposit of urates. On September 28th, $70 \mathrm{oz}$. of urine were passed. On September 29th the Improvement was maintalned; the bowels were kept open with medicine. The urine had a speclfic gravity of 1030, and the albumen a mounted to 1.2 grains per oz. She was feeling the movements of the fetus quite distinctly; and the fundus uteri was about the level of the ambllicus, for the pregnancy was nearing the end of the sixth month.

Daring the following fortnight (October lst to 14th) the 
patient continued to improve In every way. The specific gravity of the urine fell to 1020 , and then to 1015 , and the albumen diminished to 0.77 grain per oz., and then to a trace. She felt very well, and rebelled greatly agalnst the strict milk diet. On October 10th it was thought to be sefe to allow her dlet. On October loth it was thought to be sefe to allow her Ittle porridge, toast, and milk padding. She was passing
$50 \mathrm{oz}$. of arine in twenty-four hours, and the bowels were being 50 oz. Of arine in twenty-four hours, and the bowels were being
moved with the help of salphate of magnesis. The thyroid moved with the help of sulphate of magnesia. The thyrold went home to be under the care of her Own doctor. Her condition was satisfactory, although there was a slight trace of albumen. The oedema had entirely disappeared from her faco, causing a somewhat strlking change in her appesranco.

In January, 1906 I obtained from Dr. Titterton the following farther notes of the case. The thyrold treatment was continued, and the patient did well untll Ostober 24 th, when Dr. tinued, and the patient did well until Ostober 24 th, when Dr.
Titterton was sent for, and found the os uteri dilating, the Titterton was sent for, and found the os uteri dilating, the
fetal hesd presenting, and labour going on. The fetas, placenta, and membranes all came away easily, and the patient recovered well. The fetus had evidently been dead for a few deys. A trace of albumen continued in the urine for a week after the lochial discharge had stopped; but it then disappeared, and the patient was quite well.

These three cases illustrate the kind of treatment it is possible to give to pregnant patients attacked by eclampsia. In each instance we were able to save the life of the mother and to allow the pregnancy to go on-surely the ideal treatment of gestatlonal eclampaia. In two out of the three cases the patient was kept in the hospital nntil the labour came on, and in the third she was allowed to go home to be under the care of her own medical attendant. In the last-named instance I was influenced, no doubt, by the dislike I have to keeping pregnant women for a long period of weeks in ordinary maternity wards filled with puerperal patients. On the other hand, if she had stayed in, it would have been possible to have kept a more strict supervision of her dlet, of the atate of the urine, etc, than could be done in private practice. The death of the Infant in the third case was disappolnting, but, on the other hand, its survival in the first case was most satis. factory; almost surprlsing if Its slze and condition be taken into account. The Infant in the second case was, as has been stated, hydrocephalic. In all the three patients recovery was complete, as is proved by reports received some months later. It is also to be remembered that these were cases of eclampsia in pregnancy, not simply of albuminuria the precursor of eclampsia.

Albumindria in Pregnancy.

Cases of albuminuria in pregnancy ought to be most successfully dealt with in a pre.maternity hospital, and no doubt in the future they will constitute the majority of the patients treated therein. As a matter of fact, there have not been many cases of this morbid form of gestation occupying the Hamilton Bed. The reason is not far to seek; it is difficult to persuade patients suffering from albuminuria to submit themselves to hospltal treatment; they do not feel sufficiently ill, and their frlends and relatives see no cause for their removal from home. As soon, however, as eclampsia declares itself, the Iriends are ready enough, nay urgent, to have the patient transported to the hospital. This is to be regretted, for there can be no doubt that it is much easier to prevent albuminuria leading on to convulslons by proper and simple treatment than to save the mother and the infant in a pregnancy complicated with eclampsia by any means of treatment. I may here refer briefly to a case of albuminuria which was treated in the Hamilton Bed while $I$ was acting as assistant physician in Prolessor Simpson's quarter in 1902.

The patient, a dairymaid, 20 years of age, was admitted to the hospital on November 9th, 1902. She had arrived at. five and a half months in her first pregnanoy. For three weeks she had moticed swelling of her hande, and about five days before had moticed swelling of her hande, and about five days before There had been no headache, no sensory phenomena, and no noticesble diminution in the amount of urine psssed. She had been in the habit of drinking much milk. On examination there was found to be marked oedema of the lower limbs and $a$ swollen distended and tender state of the labia, especially the right labium majus. Tho back also was dropsical, and so was the right hand. The face was puffy and pale. There were the usual signs of pregnancy, and the fundus uteri was felt lying usual signs $f$ pregnancy, and the fundus uteri was felt lying oedema of the abdominal walls, and the exaet lie of the fetus could not be made out, but the fetal heart was heard (rate, 160) on the right side, below the level of the umbilious. The examination of the urine showed the presence of albumen, 14 grams per litre; the ures measured 2 grains per ounco.
On admission, the patient was put on a rigid milk diet; the bowels were moved by means of castor oil, and a Southey's tube was pat in the rlght labium. On November 10th the urea had increased to 3 grains per onnce, the albumen measured 13 grams per litre. Five grains of thyroid extract were given 14 grams per litre. Five grains of thyroid extract were given night and morning; this was continued for a fortnight. The bowels were kept acting freely by means of Henry's solution.
On November 16th the albumen bad fallen to $\frac{3}{4}$ gram per lltre, On November 16th the albumen had fallen to $\frac{3}{4}$ gram per litre,
and ten days later there was onjy a trace. The oedems rapid]s diminished. The temperature was normal, and the pulse.rate slow $(60$ to 70$)$. On December ist the. red blood corpuscles numbered 4,512,000, and the white 9,266 ; there was 30 per cent. of heemoglobin. She left the hospital on December 5th; the oedema had almost disappeared. She was now more then six months pregnant. She felt quite well. The fetus was allve.

Other Maladies of Pregnancy.

About 40 cases, in addition to these I have reported have been treated in the Hamilton Bed since its establishment. I may refer to some of those desilt with under my own care. There was, for Instance, a case of psendoangina with extremely curious and enigmatical symptomes and signs; the nervous symptoms improved markedly after labour. This patient was in the hospital for nearly a month during October, 1905. Her child was born with a supernumerary auricle on the left side of the neck just above the clavicle. Another interesting case was one of old-standing hemiplegia with contractures; she was under observation for some time. Her infant also had a malformation-two congenital teeth in the lower jaw. This association of malformations in the infant and maternal nervous maladies has been noticed by me before. Then, again, there was a case of prolapse of the pregnant uterus at the sixth month. The displaced organ was replaced with some difficulty and a pessary inserted. The support, however, was insufficient, and so the patient had to be kept in bed and the vagina had to be packed daily; at a later date the pessary sufficed; and at a still later the patient was allowed to go home, the displacement not having recurred. Yet again there have been several anxious cases of heart disease complicating. pregnancy, and calling in one instance for the induction of premature labour; the infant in this last-named case only lived for one month.

Other maladies have been treated, such as myzoma of the chorion, threatened abortion, accldental haemorrhage, grave anaemia, hyperemesls, and hydramnios; but, as these were dealt with during the terms of office of $\mathrm{my}$ colleagues, I shall not refer to them. I regret that some degree of confusion seems to have been present in the minds of some of our resident physicians as to the nature of the cases that might find admittance to the Hamilton Bed. The very fact that a patient was in labour at the time of admission to the hospital ought, of courge, to have debarred her from treatment in a bed set apart for the diseases of pregnancy; and yet In the officlal case-book I find detalls of several cases of eclampsia which seem to have been in labour either at the time they were received into the hospital or within a few hours afterwards, and I notice one case of ruptured uterus which came in after labour had been golng on for hours. Obviously it is impossible to form correctnotions regarding the effect of preventlve treatment in pregnancy in such cases. Again, I hardly think that it is wise to include cases which have been waiting in hospital for a few days before the induction of premature labour by such methods as the bougle or the hydrostatlc bag. These conslderations and others which have forced themselves upon me during the past few years have led me to make the following suggestions: First, in respect to pre-maternity beds in maternity hospitals, and, secondly, in regard to pre-maternity wards or pavilions or hospltals. I may add that apparently no patient has died in the Hiamilton Bed duning the progress of her pregnancy; but there have been a number of deaths within longer or shorter times of delivery. There was, for instance, the case of Caesarean section, to which I have already referred; there were two of death after dellvery in advanced cases of heart and kidney disease; there was one death alter the performance of craniotomy in a patient with kidney disease; and there were several deaths from eelampsia, some of whlch should In no way be associated with the Hamilton Bed; for they. were in labour when they were brought into the hoopital; or they were in convulsions, which in a fow hours induced labour pains. On the other hand, some of the most swe. 
cessful cases of preventive treatment, such as the three patients suffering from eclampsia whose histories I have cecorded above, were not entered In the case-book at all. The only reason which I have been able to discover for these irregularities was a notion in my resident physicians' minds that all Hamilton Bed patients required to be seriously ill, and that the Hamilton Bed case-book was mostly for the recording of disastrons eclampsiss.

From the experience I have had of the treatment of patlents in the Hamilton Bed I would make the following puggestions:

\section{Sugargmions for Pre mathrnity Beds in Maternity} Hospitals.

1. The pre maternity bed or beds should be strictly ceserved for the reception of cases of morbld pregnancy.

2. If a patient suffering from one of the maladles of pregnancy pass into labour within lorty-eight hours of her reception into the pre-maternity bed she shall not be regarded as a pre-maternity case, for, obvlously, such a brief stay does not permit of any satisfactory attempt towards the effective treatment of her malady.

3. The pre-maternity beds should be placed in a ward by themselves, and should not be located in the ordinary ward uged for the puerperal patlents.

4. A slater should be in charge of these beds who has had a surglcal and medical as well as an obstetric experlence, for the nursing required wlll in most instances be more strictly medical or surglcal than obstetrical.

5. No attempt should be made to adapt the diet of puerperal patients for the use of the pre-maternity patients, for, as a general rule, the latter require quite different lood.

6. : Special case-taking formy should be used for the prematernity cases ; it is unsatisfactory to attempt to utilize the back leaf or the margins of the ordinary forms or charts for the noting of the many clinlcal details which are of value and which ought to be recorded in such cases.

7. A special case book should be kept in which every patient who has been in the pre-maternity bed for a period of more than forty-elght hours should be entered. If this is not done patients may enter and pass through the hospital and leave no record behind them at all. If, for Instance, a patient suffering from hyperemesis gravidaram or from retroversion of the pregnant uterus be treated snccessfully in the pre-maternity bed, she will probsbly not remain in the hospltal for her deliveny, hnt will leave at once for her home. This has happened on several occasions in my quarter in the hospital, and some interesting material has thus been lost.

8. In pre maternity cases special attention should be paid to urine analysis, to examination of the blood and nervous system, to ophthalmoscoplc Investigations, and to a detailed and thorough examination of the signs and symptoms of pregnancy, Including estimations and descriptions of the fetal heart and of the fetal movements. (During the past three years one of my resident ohysicians has made a special study of the blood in pregnancy and labour, while another has investigated the tendon reflezes, and yet another has made a series of urinalyses.)

9. Suitable cases for treatment in pre-maternity beds are pregnant patlents suffering from albuminuria, heart disease, intractable vomiting, pulmonary disease, hepatic disesse, ansemls and other blood disorders, and varions nervous maladles, especially epilepsy, hystero.epllepsy. hysteria, chorea gravldarum, and paralysis. Diseases of the reproductive organs themselves, such as retroversion of the gravid uterus, threatened abortion, pruritas and oedems valvae, uterine prolapse, cystocele, vulvar inflammation and abscess, uterine myomats as complicatlons of pregnancy, and suspected ectopic gestation might all verg properly be treated in pre-maternity beds. Hydramnlos : and other conditlons (anch as twins) leading to over.distension of the nterus might likewlse derive benefit; and ceses of suspected hydatid mole, of placental haemorrhage, missed abortion, or antenatal death or deformity might with advantage be kept under observation. Further, patlents who have suffered in past pregnancies from "habitaal" abortion, "habitual" fetal death or disesse, "habitual" prematerity or postmaturity, or from eclampsia; might be dieted, kept at rest, or treated with medicinal means, etc., in future pregnancies, in order, If posslble, to prevent the recurrence of these reproductive disasters. Patlents who are pregnant and have already suffered from eclamptlc seizures are not so-suitahle for pre-maternity treatment unless it is clear that labour pains have not begun and show no tendency to begin; but even in these cases good results may sometimes be obtained, although conservative treatment after the occurrence of eclampsis is much less hopeful than it is during the pre-eclamptic stage when albuminuris alone is present.

10. Cases which are unsuitable for treatment in a prematernity bed would seem to be Infectlons fevers (scarlet lever, measles, ty phoid, erysipelas, etc.) occurring as complications of pregnancy (these should go to the fever hospital), and cases of insanity (manla or melancholla) in pregnancy (these should receive asylum treatment).

11. It is doubtful whether cases of syphilis should be dealt with, but I think that patlents suffering irom gonorrhoeal vaginitis and valvitis might be taken in and treated during their pregnancles. Alcoholiem and dipsomanla in pregnant women might perhaps be reganded as suitable fur treatment, but actual delirinm tremens shonld find a home elsewhere untll the acute symptoms:have passed.

\section{Sugghstions for Pri-materitit Wards or} Hospitals.

1. The pre-maternity hoepital or ward should be connected with the maternity hospital, but should not be included in $1 t$; there should, where practicable, be two buildings connected by a covered passage or gallery.

2. The pre-maternity portion should resemble closejy an ordinary general hospital in its construction and arrangement rather than a maternity hospltal.

3. The management of the pre-maternity should be kept as far as possible distinct from that of the maternity. The nursing, the diet, the regimen, and to some extent the medical treatment required all differ from those in use In a maternity hospltal.

4. The speclal details of diagnosis and treatment which have been referred to under the pre-maternity bed could all be carried out, and ought to be carried out, in the prematernity hospital or ward.

5. The same cases whlch were enumerated as sultable for treatment in a pre-maternity bed will, of course, be fit and proper cases for a pre maternlty hospital; but, In addition, pregnant patients suffering from syphilis might be received in a special ward, and more attention might, perhaps, be paid to the alcobollc cases.

6. There should be a resident pbysician whose bufiness it would be to take charge of the pre-maternity hospital. The physician of the maternity bospital would make a visit each day, and there might profitably be a consulting physiclan and surgeon for the pre-maternity. It would be of Immense advantage if young graduates, such as Carnegie Fellows or Scholars, would take up the investigation of problems of metabolism, of excretion, of cirealatlon, etc., in pregnancy; the work could be done. In connexion with pre-maternity hospitals, but actual residence of the workers would not be necessary.

7. The supervention of labonr would olways be the signal for the transference of a patient from the prematernity to the maternity hospital; the patient's record would go with her, and would serve as a guide for treatment and diagnosis in the other part of the building. It may be found to be an advantage to give beds to patients awaitlng the Induction of premature labour for contracted pelvis; during their stay in the pre maternity hospital they could be under close medical observation, and unsuspected morbid states of kidneys or of lungs, etc., might be detected; the exact age of the pregnancy might also be calculated, and possibly the early stages of the Induction might even be carried ont in the pre-maternity. At the same time, the pre maternity hospltal is essentially for the reception of morbid. pregnancies.

1 Rep. Proc. Nat. Conf. Infantíle Mortality. London, 1806, p. 155 2 BRITISH MEDical. JouRAL, vol. ii, 1907, p. 421.

Cigarettig Legisluation.-According to the New York Medical Record the:Supreme Court has declared the anticigarette law passed by the last Illinois Legislature uncongtitutional on technical grounds. The law as passed contained provisions not enumerated in its title and did not prohibit the sale of cigarettes containing " pure tobacco." 